\title{
NATIONALIST MOBILIZATION IN THE RUSSIAN FAR EAST DURING THE CLOSING PHASE OF THE CIVIL WAR
}

Three major factions in the Russian Civil War in the Far East engaged in nationalist mobilization coming up with different rhetorical tropes and images in the 1920-1922 period. The ultra-royalist faction led by Mikhail Konstantinovich Diterikhs, which in 1922 controlled the Provisional Priamur Government in Vladivostok, portrayed the Romanovs as redeemers who had ended the "dark age" of the Time of Troubles (1598-1613) and called for a new Zemskii Sobor to elect a Romanov Tsar for the sake of new redemption from the "foreign" Bolsheviks. The socialist faction of the Far Eastern Republic (FER), taken over by the Bolsheviks, focused on the grievances caused by the Romanovs' policies and the clashes with Japan and stressed the future role of the Russians as the first nation of toilers to lead the global struggle for social justice. The popular monarchist faction, established by Grigorii Mikhailovich Semenov, tried to find a middle ground by emphasising the popular role in ending the Time of Troubles and agitating for an elected muzhik Tsar. The ultra-royalist and monarchist rhetoric failed to mobilize the people of the Far East who did not identify with the Eurocentric images of the past and rebuked the cooperation between the monarchists and Japan. The socialist claims that the Romanovs and the Japanese accounted for the degraded present proved more relevant in view of the regional historical narrative featuring a series of conflicts with East Asian states, while the economic rather than racial interpretation of the Japanese policies and the inclusive character of socialism did not alienate ethnic minorities from the socialist faction. Refs 22.

Keywords: Russian Civil War, nationalism, Russian Far East, socialism, monarchism.

For citation: Sablin I. V. Nationalist mobilization in the russian far east during the closing phase of the civil war. Vestnik of Saint Petersburg University. History, 2017, vol. 62, issue 1, pp. 18-25. DOI: $10.21638 / 11701 /$ spbu02.2017.102

\section{И. В. Саблин}

\section{НАЦИОНАЛИСТИЧЕСКАЯ МОБИЛИЗАЦИЯ НА РОССИЙСКОМ ДАЛЬНЕМ ВОСТОКЕ НА ЗАКЛЮЧИТЕЛЬНОМ ЭТАПЕ ГРАЖДАНСКОЙ ВОЙНЫ}

Гражданская война в азиатской части бывшей Российской империи не закончилась с падением режима Александра Васильевича Колчака. На российском Дальнем Востоке ее активная фаза продолжалась по крайней мере до 1922 г. На завершающем этапе конфликта (1920-1922 гг.) три основные группировки апеллировали к националистическим образам с целью мобилизации местного населения. Ультрароялисты под предводительством Михаила Константиновича Дитерихса, которым в 1922 г. удалось установить контроль над Временным Приамурским правительством с центром во Владивостоке, представляли Романовых в качестве спасителей в период Смутного времени (1598-1613 гг.) и призывали созвать новый Земский собор для выборов царя из Дома Романовых во имя спасения от «чужеземных» большевиков. Социалисты - большевики, меньшевики, эсеры и другие группировки - акцентировали внимание населения на страда-

Sablin Ivan - PhD in History, Senior Research Fellow, Center for Historical Research, National Research University Higher School of Economics, Saint Petersburg, 16, ul. Soiuza Pechatnikov, St. Petersburg, 190008, Russian Federation; isablin@hse.ru

Саблин Иван Валерьевич - PhD, старший научный сотрудник, Центр исторических исследований, Национальный исследовательский университет «Высшая школа экономики», Санкт-Петербург, Российская Федерация, 190008, Санкт-Петербург, ул. Союза Печатников, 16; isablin@hse.ru

The article was prepared within the framework of the Basic Research Program at the National Research University Higher School of Economics (HSE), project "Transformation of Regimes of Governing Diversity: Continuity of Imperial Practices and Ruptures of Post-imperial Political Imaginaries in the History of Russia" (TZ-51) in 2017, and supported within the framework of a subsidy granted to the HSE by the Government of the Russian Federation for the implementation of the Global Competitiveness Program.

() Санкт-Петербургский государственный университет, 2017 
ниях, вызванных политикой Романовых и столкновениями с Японией, и подчеркивали будущую роль русских как первой нации трудящихся в глобальной борьбе за социальную справедливость. Несмотря на контроль большевиков над Дальневосточной республикой (ДВР), умеренные социалисты смогли продолжать свою деятельность до конца 1922 г. Народно-монархическая (правопопулистская) группировка, созданная Григорием Михайловичем Семеновым, пытаясь найти компромисс, апеллировала к идее спасения в ходе Смутного времени, но при этом подчеркивала роль народа в этом спасении и потому призывала к выборам мужицкого царя. Ультрароялистская и монархическая риторика оказалась бесполезной в мобилизации населения Дальнего Востока, которое не солидаризировалось с европоцентристскими образами прошлого и осуждало сотрудничество монархистов с Японией. Возложение на Романовых и японцев ответственности за упадок соответствовало основному нарративу региональной истории, построенному на серии конфликтов с восточноазиатскими государствами, в то время как экономические, а не расовые интерпретации японской политики и инклюзивный характер социализма не привели к разрыву социалистов с национальными меньшинствами. В статье деятельность указанных группировок рассматривается с точки зрения конструктивистского и экономического подходов к национальной мобилизации. Исследование вводит в научный оборот документы из фондов Российского государственного исторического архива Дальнего Востока (г. Владивосток) и Государственного архива Хабаровского края (г. Хабаровск). Библиогр. 22 назв.

Ключевые слова: Гражданская война, национализм, Дальний Восток, социализм, монархизм.

In the summer of 1922 the Russian Monarchic Society "The Faith, the Tsar, and the People" circulated a proclamation in Vladivostok. In this proclamation, Metropolitan Antonii of the Russian Orthodox Church appealed to the anti-Bolshevik military forces in the Maritime Region, mainly the kappelevtsy and the semenovtsy (the forces formerly under the command of Vladimir Oskarovich Kappel' and Grigorii Mikhailovich Semenov), and called for creating a people's volunteer corps for defending "the rights of the faith and the Russian tradition." Antonii drew a direct connection between the Russian Civil War which in the Russian Far East protracted at least until 1922 thanks to the Japanese military presence and involved the creation of the Far Eastern Republic (FER, 1920-1922), the Provisional Priamur Government (1921-1922), and several other competing state formations - and the Time of Troubles (1598-1613) claiming that his appeals were identical to those the "Nizhny Novgorod Army" made on its way to Moscow in 1612. Antonii nevertheless muted the popular element of the nationalist historical myth by stressing its monarchist and anti-foreign aspects and putting the 1612-1613 events in line with the Kazan campaign of Ivan the Terrible (1552) and the Polish campaign of Alexei Mikhailovich (1654). According to Antonii, the main objective of the new volunteer corps was to revive the old "Russian Orthodox Russia" with "a Tsar from the decendants of Patriarch Filaret and Mikhail Fedorovich Romanov" [Obrashchenie mitropolita Antoniia 1922, 11. 395-396].

The proclamation was part of a massive propaganda campaign launched by the crumbling Vladivostok-based Provisional Priamur Government under Spiridon Dionis'evich Merkulov which challenged the Bolshevik-dominated Chita-based Far Eastern Republic from May of 1921. It was not only the anticipated withdrawal of Japanese forces which accounted for the crisis, but also the constant splits among the anti-socialists (first, between Merkulov and Semenov and later between Merkulov and the kappelevtsy who handed dictatorial powers to Mikhail Konstantinovich Diterikhs in the summer of 1922) caused by personal rivalries and the disagreements about the ideological foundations of the antiBolshevik struggle [Mukhachev 2003]. Having united in negative terms in response to the 
predominantly socialist FER (as the anti-socialists), the Vladivostok government desperately needed an idea which could mobilize the Far Eastern population. Even though nationalism seemed best suited for popular mobilization, it had to be defined and communicated to the people who were expected to give their lives for a particular political faction. Furthermore, the socialist coalition which stood at the foundation of the FER and was taken over by the Bolsheviks by 1922 also engaged in nationalist popular mobilization.

The struggle between the FER and the Provisional Priamur Government, as well as within the two [Azarenkov 2001], led to emergence of three major nationalist narratives which could be loosely attached to three competing factions (ultra-loyalist, socialist, and popular monarchist). The first faction, represented by Antonii, can be referred to as the ultra-royalists due to their unconditional support for monarchy and the Romanov family. This faction, which received the backing of Diterikhs in 1922, portrayed the Romanovs as redeemers who ended the "dark age" of the Time of Troubles and called for a new Zemskii Sobor to elect a new Romanov Tsar for the sake of new redemption from the "foreign" Bolsheviks, who were deemed German spies [Memorandum po delu monarkhicheskikh organizatsii 1922, 1l. 33-36 ob.]. In this respect the nationalist myth which interpreted the Time of Troubles as the Polish occupation rather than a complex political crisis of early modern Russia was to be replayed in the Far East. Vladivostok was supposed to simultaneously take the place of Nizhny Novgorod (as the center of mobilization and the starting point of a campaign directed at Moscow) and of Moscow (as the site of the Zemskii Sobor).

The second, Bolshevik-dominated socialist faction (first, under Aleksandr Mikhailovich Krasnoshchekov and later under Iakov Davidovich Ianson, Nikolai Mikhailovich Matveev, and others), which effectively controlled the FER since the autumn of 1920, was at the opposite side of the political spectrum. It put forward a type of socialist nationalism which was popular in the late Russian Empire and especially after the February Revolution of 1917 and promoted by the Socialist Revolutionaries (SRs), the Mensheviks, and minority socialist nationalist parties (the Jewish Labor Bund, the Armenian Revolutionary Federation, and others). In the Far East, where the SRs and Mensheviks retained some space for political activism despite the already ongoing repressions, socialists focused on the grievances caused by the Romanovs' policies and the clashes with Japan and stressed the future role of the Russians as the first nation of toilers in leading the global struggle for social justice, in the form of World Revolution or by setting an example of progressive reforms. The Bolsheviks not only adopted the rhetoric of their socialist opponents, but also managed to strip this version of nationalism of its democratic connotations putting forward the so-called "democratic centralism" and the dictatorship of the proletariat instead. Despite their anti-democratic stance, they remained in the realm of republicanism, at least rhetorically.

Seeking to broaden the popular support of the anti-Bolshevik movement, but at the same time fearing to alienate radical monarchists, Semenov launched the creation of the third, popular monarchist faction. He tried to find a middle ground between ultra-royalists and republicans by appealing to the redemption narrative of the Time of Troubles, but stressing the popular role in ending the "dark age" and agitating for an elected $m u$ zhik Tsar. Semenov circulated a dubious document, "the Manifesto of the Russian Peasant Party" ostensibly adopted in Nizhny Novgorod but most likely composed and printed in Transbaikalia, which called for making Semenov "the Russian Peasant Dictator" already in the spring of 1920 [Prikaz 1920, 1l. 83-84 ob.] and later for electing a peasant (or at least a 
Cossack) Tsar. In the summer of 1921, a pamphlet called The Muzhik Tsar was circulated in Vladivostok. Although Semenov himself was outplayed by Merkulov and was forced to leave the Russian Far East in 1921, his supporters joined the newly formed society "The Tsar and the People." "The Tsar and the People," which soon transformed into the above-mentioned "The Faith, the Tsar, and the People," was also backed by Merkulov and Diterikhs which blurred its affiliation to either of the two monarchist projects [Memorandum po delu monarkhicheskikh organizatsii 1922, 1l. 33-36 ob.].

Despite these organizational entanglements, the two approaches to monarchist revival could still be traced in the documents. Apart from that, there certainly was a liberal view of nationalism in the Far East represented, for instance, by the Constitutional Democrats Lev Afanas'evich Krol' and Vladimir Aleksandrovich Vinogradov [Krol' 1921], but the liberals failed to achieve prominence either in the Far Eastern Republic or the Priamur State Formation and became irrelevant for the fighting factions in the summer and fall of 1922. Their vision nevertheless heavily influenced Semenov's rhetoric, while the more liberally-inclined trade and industrialist delegates of the Priamur Zemskii Sobor created an opposition to the ultra-royalists there [Mukhachev 2003].

The key questions of this article are how the three dominant nationalist narratives, socialist, ultra-royalist, and popular monarchist, differed from one another and why the Bolshevik-backed socialist rendering of the Russian nation succeeded: in the fall of 1922 the FER joined Soviet Russia through a parliamentary decision which caused no major protests in the region, while the Far Eastern monarchists failed to attract broad support not only in the region, but also in emigré circles. A combination of economic and constructivist approaches to studying nationalist mobilization helped grasping the differences between the three narratives and explaining the ineffectiveness of the monarchist mobilization.

Nationalist mobilization includes formulation and utilization of past and present grievances of the population and articulation of its potential gains by political actors [Regan and Norton 2005]. Here not only unfavourable economic conditions [Fearon and Laitin 2003], but also the solutions for economic and social problems offered by political actors play a major role. According to the Far Eastern and Siberian representatives in the State Duma of the Russian Empire, the failures of the Romanovs' foreign policy and subsequent clashes with the Qing Empire during the Boxer Rebellion (1899-1901), which featured the Battles on the Amur River and an anti-Chinese pogrom in Blagoveshchensk, with Japan in the Russo-Japanese War (1904-1905), and ultimately with the Central Powers in the Great War (1914-1918) contributed to death, suffering, impoverishment, and other grievances of the Far Eastern population. The Tsarist domestic policies, including the refusal to introduce zemstvo self-government in the region, suppression of economic initiative, and abolition of the regional free trade zone [Gosudarstvennaia duma, chetvertyi sozyv, chetvertaia sessiia 1916, col. 2701-2713], also contributed to the emergence of the "degraded present" [Levinger and Lytle 2001].

Although the Bolsheviks were considered by many to be the initiators of the Civil War [Obrashchenie atamana Semenova 1920, 1. 54], it was Japan's intervention and the activities of its Russian allies, Semenov and Merkulov, which protracted the crisis. Speaking at the constituent conference of the FER in the fall of 1920, Matveev described the intervention as occupation. "[W]e did not see Russian people, peasants, we saw Japanese, Koreans, Chinese. Through the window of the railway car it seemed that we traveled across a foreign coun- 
try and not across the Russian Maritime Region." At the same conference, Krasnoshchekov stressed, however, that it was not a racial conflict between Europe and Asia, contrary to a prominent imperial discourse of the "yellow peril" [Schimmelpenninck van der Oye 2001], but an economic one between the imperialists and the toilers. He called the Chinese and Koreans brothers and condemned Japanese imperialism [Protokol 1920, 1l. 1-15 ob.].

The socialists also offered a solution to the economic grievances of the regional population promising to ensure the right of workers "to build its own life freely" in a peaceful context. Unlike the ultra-royalists and popular monarchists, the socialists muted the slogans of class warfare and claimed that they sought peace [Protokol 1920, 11. 1-15 ob.]. Despite the violent policies of Soviet Russia, the anti-war rhetoric made the Far Eastern socialists much more attractive to the regional population than their contenders who appeared to campaign for the continuation of the Civil War. The Bolsheviks did not dismiss the possibility of violence, but an operation against the Provisional Priamur Government and, possibly, against the Japanese in the Maritime Region was expected to be much shorter and therefore less damaging for the regional population than the Moscow campaign advocated by Antonii and his political allies. Instead of offering the people intelligible economic gains in the future, the anti-Bolsheviks in Vladivostok tried to prove that the Provisional Priamur Government had already saved the population from the grievances similar to that in Soviet Russia, "the horrors of the unprecedented famine that spread across whole Russia." Since the people had already achieved economic gains, they now were expected to become the heroes who were ready to fight and die "for the great Russian idea" [Ot komiteta 1922, 1. 146].

Apart from dealing with the past and present grievances of the Far Eastern population and articulating their future gains, the three factions also had to outline the imagined community with which the people could identify. Given that all three factions used Russian and none of them engaged in anti-religious policies (including the Bolsheviks in the FER), it was not language or religion [Anderson 1991], but rather history and destiny which were supposed to consolidate the Russian imagined community and mobilize the population [Coakley 2004]. The theory of collective action frames proved especially helpful when grasping the differences between and evaluating the effectiveness of the three factions [Levinger and Lytle 2001].

All three factions agreed on the, perhaps, exaggerated depictions of the degraded present (though they held different actors accountable for the crisis), but had different approaches to the past and the future. The ultra-royalists and popular monarchists focused on the idealized images of the past. Contrary to Antonii's appeals to the deeds of individual tsars, Semenov's faction stressed the role of the people in ensuring this idealized past in 1920. The non-partisan nature of the peasantry was supposed to bring "peace to all the people of Russia" and destroy all other parties "which only ruined Russia by their arguments, quarrels, fights and murders" [Obrashchenie atamana Semenova 1920, 1. 54]. In 1922 "The Faith, the Tsar, and the People" continued this line of argumentation by stressing the non-partisan nature of monarchy in its appeals to the peasants, workers, and Cossacks [Obrashchenie k krest'ianam 1922, 1. 397] and therefore its capability to bring back the "golden age" free from party politics.

Unlike the monarchists, the Bolsheviks did not offer any idealized images of the past, apart from the most recent past of the February Revolution and the Civil War which liberated the people and the "age of struggle" pertaining to settler colonization of Siberia and the 
Russian Far East. The recent past was in fact the starting point of the new future, in which the Russian nation had to play a special role. Speaking at the session of the Provisional People's Assembly of the Far East in the summer of 1920, before the unification of the FER, the Menshevik Aleksei Ivanovich Kabtsan put the interests of the nation in front of those of the class. The main objective of the socialists was to secure the Far East for the Russian state, which, according to Kabtsan, only Soviet Russia could do. Even though the Far Eastern Mensheviks opposed the Soviet political system, they were ready to sacrifice democracy to national unity. For Kabtsan there were in fact no contradictions between the interests of the nation and the class in the Russian case anymore. Since the interests of the toilers (workers, peasants, and some intellectuals) coincided with "the interests of the development of the whole society," the workers substituted the bourgeoisie as the leader of the Russian society and "the carrier of the national idea" [Stenograficheskii otchet 1920, 1l. 1-15].

Although the Bolsheviks dismissed the notion of class and political compromise and persecuted their socialist opponents in the Russian Far East in 1921-1922, as in Soviet Russia, they took over the discourses of the Mensheviks and the SRs and stressed the national unity of the toilers in the Far East and Soviet Russia when explaining the liquidation of the FER in November 1922. Some Bolsheviks also pointed that the independence of the FER was irrelevant in view of the continuing global civil war, in which Soviet Russia as the country of the "insurgent proletarians" needed the efforts of all Russian toilers [Otchet o rabote 1923, 1l. 1-9]. Besides, the proletarian interpretation of the Russian nation did not make other nations its natural opponents. On the contrary, the cooperation between socialists of various backgrounds after the February Revolution and the readiness of the Bolsheviks to support autonomies of post-imperial minorities after 1918, as well as their internationalist agenda, made the socialist version of nationalism inclusive and therefore acceptable for the non-Russian population of the region [Suny 1993].

With the idea of global solidarity of the toilers in their quest for social justice taken up by the socialists, "The Faith, the Tsar, and the People" attempted to find alternative connections between welfare, internationalism, and monarchy in order to reach the peasants, Cossacks, and workers. Mikhail Fedorovich was credited for "putting an end to all troubles" in Russia in 1613. Alexander II was called the Liberator who "personally emancipated the many-millioned peasantry." Alexander III, the Peacemaker, was said to be the first in the world to "found the international tribunal" of all powers for the sake of "limiting arms and ending all wars." The last appeal, which the authors of the proclamation had to clarify to their audience by noting that the tribunal was located in The Hague, reflected the monarchists' desperate attempts to translate elitist internationalism to the population [Obrashchenie k krest'ianam 1922, 1. 397].

The elitist suggestion to revoke the Russian Revolution of 1917 was also very hard to explain to the Far Eastern population. In his attempts to prove the damage of the revolution and to mitigate the explicit Eurocentrism of the Russian historical myths barely relevant to Siberia and the Far East, Antonii appealed to the figure of Fedor Mikhailovich Dostoevskii. Turning the writer into a prophet who foresaw "the bloody mutiny," Antonii claimed that Dostoevskii located Russia's future in Siberia which would launch the "new great revival" of Russia [Obrashchenie mitropolita Antoniia 1922, 1. 395]. Here Antonii attempted to utilize the ideas of Siberian Regionalism (Oblastnichestvo) which reserved a special role for Asian Russia, but these ideas developed by regional intellectuals over the nineteenth century were of little use for the monarchist cause. Not only were the dis- 
cussions of Siberia's special role launched by the exiled Decembrists and later developed mainly by socialists and liberals, but they also featured extensive criticism of European Russia in its Moscow and Saint Petersburg emanations and numerous demands for democratization and federalization in line with the North American example [Bassin 2006]. The images of penal servitude, banishment, and heresy which were ascribed to Siberia in the master narrative of Russian history [Remnev 2007], together with the special role played by Polish political exiles in the history of the region and its general religious and ethnic diversity, made Siberian Regionalism useless for the ultra-royalist project [Gosudarstvennaia duma, chetvertyi sozyv, chetvertaia sessiia 1916, pp. 2701-2713].

The Bolsheviks were more successful in dealing with the region's peculiar history, providing its nuanced rendering. The Bolsheviks effectively used the ideas of Siberian Regionalists when comparing North Asia to North America and applauding the efforts of the Russian settlers in turning the "no man's land" into a part of "human civilization." At the same time, during the liquidation of the FER they dismissed the main Regionalist idea that Asian Russia was a colony of European Russia and denounced the claims for regional autonomy [Otchet o rabote 1923, 11. 1-9; Protokol 1920, 11. 1-15 ob.].

The references to the recent past of the February Revolution and the Civil War and to the Russian settlement efforts, as well as the redefinition of the Russian nation as a nation of toilers, proved to be much more relevant (or at least less irrelevant) to the regional population than the appeals to the Time of Troubles, Russian tsars, and even the recent Great War made by the monarchists. The monarchists failed to convince the population to fight against the alleged German spies and sacrifice themselves for the sake of revoking the Russian Revolution of 1917. The popular monarchists failed to create a middle ground between ultra-royalists and liberals. Although the Zemskii Sobor convened in the summer of 1922 in Vladivostok, its participants did not reinstate monarchy, while the House of the Romanovs did not offer any candidates for the throne and did not even respond to the invitations of the Far Eastern monarchists [Memorandum po delu monarkhicheskikh organizatsii 1922, 1l. 33-36 ob.].

The people of the Far East did not identify with the Eurocentric images of the past put forward by the monarchists and rebuked their cooperation with Japan. The socialist claims that the Romanovs and the Japanese accounted for the degraded present proved more relevant in view of the regional historical narratives, while the economic rather than racial interpretation of the Japanese policies and the inclusive character of socialism did not alienate minorities from the socialist faction.

\section{References}

Anderson B. Imagined communities. Reflections on the origin and spread of nationalism. London, Verso, 1991, $224 \mathrm{p}$.

Azarenkov A. A. "Demokraticheskii kompromiss." Ideia "bufera" na Dal'nem Vostoke v planakh i taktike politicheskikh sil - uchastnikov Grazhdanskoi voiny v Rossii, ianvar' 1920 - ianvar' $1921 \mathrm{gg}$. ["Democratic compromise." The idea of a "buffer" in the Far East in the pans and tactics of political groupings participating in the Russian Civil War, January 1920 - January 1921]. Komsomolsk-onAmur, Komsomolsk-on-Amur State Pedagogical University Press, 2001, 152 p. (In Russian)

Bassin M. Imperial Visions. Nationalist Imagination and Geographical Expansion in the Russian Far East, 1840-1865. Cambridge, Cambridge University Press, 2006, 348 p.

Coakley J. Mobilizing the past: nationalist images of history. Nationalism and Ethnic politics, 2004, vol. 10, no. 4 , pp. 531-560.

Fearon J.D., Laitin, D.D. Ethnicity, insurgency, and civil war. American Political Science Review, 2003, vol. 97, no. 1 pp. 75-90. 
Gosudarstvennaia duma, chetvertyi sozyv, chetvertaia sessiia. Stenograficheskie otchety, chast' 2: zasedaniia 17-37, s 9 fevralia po 15 marta 1916 g. [The Fourth State Duma, Second Session. Verbatim reports, part 2: meetings 17-37, from February 9 to March 15, 1916]. Petrograd, Gosudarstvennaia tipografiia [State Print. House], 1916. (In Russian)

Krol' L. A. Za tri goda. Vospominaniia, vpechatleniia i vstrechi [Over three years. Memories, impressions, and meetings]. Vladivostok, Print. of Publ. House "Svobodnaia Rossiia", 1921, 212 pp. (In Russian)

Levinger M., Lytle, P.F. Myth and mobilisation: the triadic structure of nationalist rhetoric. Nations and Nationalism, 2001, vol. 7, no. 2, pp. 175-194.

Memorandum po delu monarkhicheskikh organizatsii N73 sostavlennyi upolnomochennym Primgubotdela GPU, 1922 [Memorandum on the case of monarchist organizations No. 73, compiled by the plenipotentiary of the Maritime Provincial Department of the State Political Directorate, 1922]. Gosudarstvennyi arkhiv Khabarovskogo kraia [State Archive of the Khabarovsk Territory] (GAKhK), f. R-1058, op. 1, d. 1, 1l. 33-36 ob. (In Russian, unpublished)

Istoriia Dal'nego Vostoka Rossii [History of the Russian Far East]. Ed. by B. I. Mukhachev. Vol.3, book 1: Dal'nii Vostok Rossii v period Revoliutsii 1917 goda i Grazhdanskoi voiny [The Russian Far East during the Revolution of 1917 and the Civil War]. Vladivostok, Dal'Nauka Publ., 2003, 631 p. (In Russian)

Obrashchenie atamana Semenova k zabaikal'tsam, ko vsem rossiianam, 18 marta 1920 g. [Proclamation of Ataman Semenov to Transbaikalians, to all Russians, March 18, 1920]. Gosudarstvennyi arkhiv Zabaikal'skogo kraia [State Archive of the Transbaikal Region] (GAZK), f. 334, op. 2, d. 40, 1. 54. (In Russian, unpublished)

Obrashchenie k krest'ianam, kazakam, rabochim i intelligentsii, 1 iiulia $1922 \mathrm{~g}$. [Proclamation to the peasants, Cossacks, workers, and intellectuals, July 1, 1922]. Rossiiskii gosudarstvennyi istoricheskii archiv Dal'nego Vostoka [Russian State Historical Archive of the Far East] (RGIA DV), f. R-4699, op. 1, d. 407, 1. 397. (In Russian, unpublished)

Obrashchenie mitropolita Antoniia k armii primorskogo pravitel'stva, 1922 [Appeal of Mitropolitan Antonii to the army of the maritime government, 1922]. Rossiiskii gosudarstvennyi istoricheskii archiv Dal'nego Vostoka [Russian State Historical Archive of the Far East] (RGIA DV), f. R-4699, op. 1, d. 407, 1l. 395396. (In Russian, unpublished)

Ot komiteta nesotsialisticheskikh organizatsii gor. Vladivostoka Vremennomu Priamurskomu pravitel'stvu, 26 maia 1922 g. [From the Committee of Non-Socialist Organizations of Vladivostok to the Provisional Priamur Government, May 26, 1922]. Gosudarstvennyi arkhiv Zabaikal'skogo kraia [State Archive of the Transbaikal Region] (GAKhK), f. R-1058, op. 1, d. 1, 1. 146. (In Russian, unpublished)

Otchet o rabote Narodnogo Sobraniia DVR II sozyva, 1923 [Report on the activities of the Second People's Assembly of the FER, 1923]. Gosudarstvennyi arkhiv Zabaikal'skogo kraia [State Archive of the Transbaikal Region] (GAKhK), f. R-1115, op. 1, d. 2, 1l. 1-9. (In Russian, unpublished)

Prikaz №35 po Aziatskoi konnoi divizii, 9 marta 1920 g. [Order no. 35 to the Asian Cavalry Corps, March 9, 1920]. Rossiiskii gosudarstvennyi voennyi arkhiv [Russian State Military Archive] (RGVA), f. 39454, op. 1, d. 7, 11. 83-84 ob. (In Russian, unpublished)

Protokol pervogo zasedaniia Konferentsii oblastnykh pravitel'stv Dal'nevostochnoi Respubliki, 28 oktiabria $1920 \mathrm{~g}$. [Minutes of the first meeting of the Conference of Regional Governments of the Far Eastern Republic, October 28, 1920]. Gosudarstvennyi arkhiv Zabaikal'skogo kraia [State Archive of the Transbaikal Region] (GAKhK), f. R-1121, op. 1, d. 1, 1l. 1-15 ob. (In Russian, unpublished)

Regan P. M., Norton D. Greed, grievance, and mobilization in civil wars. Journal of Conflict Resolution, 2005, vol. 49, no. 3, pp. 319-336.

Remnev A. Siberia and the Russian Far East in the Imperial Geography of Power. Russian Empire. Space, People, Power, 1700-1930. Eds. J.Burbank, M.von Hagen, A. Remnev. Bloomington (IN), Indiana University Press, 2007, pp. 425-454.

Schimmelpenninck van der Oye D. Toward the rising sun. Russian ideologies of empire and the path to war with Japan. DeKalb, Northern Illinois University Press, 2001, 345 p.

Stenograficheskii otchet, Vremennoe Narodnoe sobranie Dal'nego Vostoka, sessiia pervaia, zasedanie tret'e, 25 iiunia 1920 g. [Verbatim report, Provisional People's Assembly of the Far East, first session, third meeting, June 25, 1920]. Gosudarstvennyi arkhiv Zabaikal'skogo kraia [State Archive of the Transbaikal Region] (GAKhK), f. R-1115, op. 1, d. 5, 1l. 1-15. (In Russian, unpublished)

Suny R. G. The revenge of the past. Nationalism, revolution, and the collapse of the Soviet Union. Stanford (CA), Stanford University Press, 1993, 224 p.

Received: 25 August 2016

Accepted: 26 January 2017 